\title{
ERRATUM
}

\section{HUME, KANT, AND FEUERBACH: WHY THE ANTHROPOMORPHIC CRITIQUE REVEALS A FALSE DILEMMA BETWEEN NATURALISTIC ATHEISM AND ANTI-NATURALISTIC THEISM - ERRATUM Chris Byron and Jesse Lopes}

https://doi.org/10.1017/S1477175619000307, Published by Cambridge University Press, 11 December 2019.

In the article 'HUME, KANT, AND FEUERBACH: WHY THE ANTHROPOMORPHIC CRITIQUE REVEALS A FALSE DILEMMA BETWEEN NATURALISTIC ATHEISM AND ANTI-NATURALISTIC THEISM', ${ }^{1}$ the first author Chris Byron was wrongly listed as Christopher Byron. This error also appeared on the contents page and in the contents list on the outside back cover. The publisher apologises for this error.

\section{Reference}

1 Chris Byron and Jesse Lopes (2019) 'Hume, Kant, and Feuerbach: Why the Anthropomorphic Critique Reveals a False Dilemma Between Naturalistic Atheism and AntiNaturalistic Theism', Think 19(54): 55-67. 